\title{
Speech Discrimination Abilities of Hearing Impaired Children using Conventional Hearing Aids and Radio Neckloop at Different Signal-to-noise Ratios
}

\author{
Asoka Moodley M.Ed (Audio)(Manchester) \\ Hearing Impaired Service, Humberside County Council, England
}

\begin{abstract}
Speech discrimination scores of 20 hearing impaired children with a mean age of 14 years were examined when using their own conventional hearing aids on the microphone setting and the radio neck loop with and without the use of the environment microphone of the radio receiver. Testing of speech discrimination was administered in noise where $S / N$ of $+20 d B,+10 d B$ and OdB were used. Electroacoustic measurements of the hearing aids used were carried out to ascertain the extent to which the frequency response was altered when the aid was coupled to the neck loop used on the telecoil setting. Results highlighted the excellent performance of individual hearing aids when the favourable $S / N+20 d B$ was used. The use of the environment microphone on the radio receiver did not significantly affect speech discrimination scores. Implications regarding the radio neck loop and the use of amplification in the classroom situation are discussed.
\end{abstract}

\section{OPSOMMING}

Die spraakdiskriminasietellings van 20 gehoorgestremde kinders met 'n gemiddelde ouderdom van 14 jaar is vergelyk tydens gebruik van hulle eie konvensionele gehoorapparate op die mikrofooninstelling en die radio neklussisteem met en sonder gebruik van die radio ontvangsmikrofoon. Spraakdiskriminasietoetsing in geraas met 'n sein tot ruisverhouding van $+20 d B,+10 d B$ en 0dB is uitgevoer. Ten einde die frekwensieresponsveranderinge te bepaal wanneer die gehoorapparaat, gekoppel aan die neklussisteem op die induksielusinstelling geplaas word, is elektroakoestiese metings van die gehoorapparate wat gebruik is, uitgevoer. Resultate het die uitstekende werkvermoë van individuele gehoorapparate in 'n gunstige sein tot ruisverhouding van $+20 d B$ beklemtoon. Spraakdiskriminasietellings is nie betekenisvol geaffekteer deur die gebruik van die omgewingsmikrofoon wat aan die radio ontvanger gekoppel was. Die implikasies rakende die radio neklussisteem en die gebruik van amplifikasie in die klaskamersituasie word bespreek.

The importance of auditory stimulation for hcaring impaired children cannot be over-emphasised. Such children, particularly those with severe or profound hearing losses, need to derive maximum benefit from amplification if they are to undergo auditory training with the ultimate aim of communication.

In the past, hearing losses of more than $85 \mathrm{~dB}$ or $90 \mathrm{~dB}$ have been considered virtually unaidable in so far as they could be expected to contribute to the recognition of specch. During the last decade, in educational situations, the writer has seen a total change in expectations. Whereas children with a hearing loss of $90 \mathrm{~dB}$ or more would have been classified as severely/profoundly deaf, and referred to schools for the deaf, nowadays, a child with a $90 \mathrm{~dB}$ loss would be expected to function as partially hearing and often would be integrated into ordinary schools. !

One of the main problems facing any hearing aid user, and especially children who integrate into ordinary classrooms, is the varying acoustic conditions throughout the school. Hearing aids amplify and possibly distort both the desired speech signals and any cnvironmental noises having components between the effective high and low frequency cut-offs. Hearing aid users have to adjust to the fact that whatever signal-to-noise ratios exist from moment to moment at the face of the microphone will also exist in their ear canals except at higher levels for both speech and noise. One of the major acoustic problems facing hearing impaired children in educational settings is noisy reverberent classrooms. (John 1957; Sanders 1965; Finitzo-Hieber 1978; Ross \& Giolas 1972).

Several studies have shown that hearing impaired listeners require a higher signal-to-noise ratio than normal listeners in order to achieve their maximum speech discrimination score. Gengel (1971) reported that hearing impaired subjects rated as relatively effortless, listening conditions of $+17 \mathrm{~dB} \mathrm{~S} / \mathrm{N}$ ratio for fluctuating noise and $+20 \mathrm{~dB} \mathrm{~S} / \mathrm{N}$ ratio for constant noise. In contrast ratios less than $+10 \mathrm{~dB}$ required so much effort that the subjects indicated that under these conditions "they would prefer not to use their hearing aids but to rely on speech reading and manual communication", (Gengel 1971). Nabelek and Pickett (1974) report that a signal-tonoise ratio of $+10 \mathrm{~dB}$ "is the lowest ratio that should be considered for hearing impaired listeners wearing hearing aids in reverberent rooms'.

\section{RADIO AIDS}

One of the ways of reducing the damaging effect of noise and reverberation is to ensure that the child receives the teacher's speech in the most favourable signal-to-noise ratio relationship possible. It seems reasonable to assume that if the distance between the teacher and the microphone of the child's amplifying system could be reduced, his ability to understand the teacher's speech should substantially increase. Hearing aids not entirely worn on the person - more commonly referred to as radio aids, seem to meet this requirement and have been used increasingly in the United Kingdom over the last $10-12$ years.

Much of the earlier research on radio aids had been concerned with design, construction, batteries, acoustic gain, dynamic range and compression (N.C.T.D. 1976, Bates and Holsgrove 1979). Markides, Huntingdon and Kettlety (1980) compared a range of hearing aids including infra red systems, radio aids and speech training units. Markides et al. reported disappointment with radio aids as they "did not fulfil their theoretical potential". However, the authors did note that in poor listening conditions, radio aids have much to 
be said for them. In recent years there has been a sharp increase in the use of Personal F.M. Systems. The "radio received" signal picked up by the child's radio receiver is passed on to his hearing aid for amplification in one of two ways:

(i) by direct connection (audio input),

(ii) by loop induction - which involves the child wearing the loop of cord around his neck and under his clothes (Neck Loop).

It is mainly to neck loops that this study is directed. In the neck loop system the child sets his hearing aids to the telecoil at "MT" position. The electrical signal from the F.M. receiver is routed to the small loop of cord worn around the neck. This neck loop emits an electromagnetic field that is picked up by the telecoil of the child's hearing aid, amplified by the aid, transduced by its receiver and delivered via the earmould to the child's ear. If the child's hearing aid does not have the "MT" facility, it is possible for him to use a receiver which has an inbuilt environmental microphone.

Both the radio neck loop and direct audio input systems are very attractive to schools and students in further education and there is now widespread use of these systems throughout the United Kingdom. However, very little is known about the ways in which incorporation of the personal hearing aid into the direct audio input or neck loop FM system alters the characteristics of the sound delivered to the child's ear and what effect these systems have on the discrimination of speech in various listening conditions.

Hawkins and Van Tasell (1982) reported that the frequency response of the hearing aid altered when used with the neck loop and they went on to suggest that "the altered frequency response due to the FM neck loop configuration can be expected to affect speech perception differently for each hearing impaired child". They found that the frequency response curves for post-aural aids in the microphone and direct audio input modes are virtually identical being $\pm 2 \mathrm{~dB}$ from $250-6300 \mathrm{~Hz}$.

Most investigators agree that the frequency response of a hearing aid inductance loop system is frequently different from that of the hearing aid operating on the microphone input. However there is some conflicting data on the nature of this difference. Hodgson and Sung (1971) report relatively greater gain in frequencies below $1 \mathrm{KHz}$ when the hearing aid is operating via the telecoil mode. Nolan (1982), on the other hand, looked at various hearing aids and was very critical of the low frequency amplification that most aids afforded on the telecoil setting. His findings are supported by Barr-Hamilton (1978), Matkin and Oslen (1970) and Huntingdon (1976) whose studies show that the low frequency gain dropped sharply when the hearing aid was switched from the microphone to the telecoil position. Sung, Sung and Hodgson (1973) noted fluctuations of between $8 \mathrm{~dB}$ to $30 \mathrm{~dB}$ when a hearing aid was switched from microphone to telecoil setting.

Kortschot (cited by Borrild (1968)) reported that hearing impaired children showed significantly better speech discrimination scores when using the inductance loop than with conventional hearing aids. On the contrary, Vargo et al (1970), found that speech signals were significantly less intelligible when the hearing aid operated on the telecoil setting than on the microphone setting. One factor that is common to all the studies, and something about which there is little -disagreement, is that changes do take place in the frequency characteristics of hearing aids when they are switched from the microphone setting to the telecoil setting.

\section{METHOD}

\section{AIMS OF THE STUDY}

The present study was undertaken with four aims in mind:
1. To examine the speech discrimination abilities of hearing impaired children using their conventional hearing aids and radio neck loop in conditions where signal-to-noise ratios of $+20 \mathrm{~dB},+10 \mathrm{~dB}$ and $0 \mathrm{~dB}$ were used.

2. To find out whether there was any significant difference in the speech discrimination scores of children when use was made of the environmental microphone on the radio receiver.

3. To examine and compare the electroacoustic characteristics of the aid set on the telecoil position coupled to the radio neck loop and the microphone setting of the aid.

4. To ascertain the noise levels generated in the hearing aid on the telecoil setting compared to the microphone setting.

\section{SUBJECTS}

Twenty hearing impaired children of average age 14 years 0 months, with an age range of 10 years 10 months -16 years 6 months, took part in this study.

The average hearing loss in the better ear averaged across the frequencies $250 \mathrm{~Hz}-4 \mathrm{KHz}$, was in the range $47 \mathrm{~dB}$ to $88 \mathrm{~dB}$.

All the children had sensori-neural hearing losses and the onset of deafness was at birth or in the first eighteen months of life. All the children were regular hearing aid users. Eighteen of the children wore binaural post-aural aids and two of the children were monaural users of post-aural aids. Relevant particulars of the children who took part in the study are shown in Tables 1 and 2 .

Table 1 Number, age, sex and hearing levels of children taking part

\begin{tabular}{|c|c|c|c|c|c|}
\hline \multirow[b]{2}{*}{ Sex } & \multirow[b]{2}{*}{ No. } & \multicolumn{2}{|c|}{ Age in years } & \multicolumn{2}{|c|}{$\begin{array}{l}\text { Hearing levels in } \mathrm{dB} \\
\text { average } 250-4 \mathrm{KHz} \text { in } \\
\text { the better ear. }\end{array}$} \\
\hline & & Меал & Range & Mean & Range \\
\hline Boys & 12 & 13.5 & $10.10-14.10$ & 72.0 & $\begin{array}{ll}49 & -87\end{array}$ \\
\hline Girls & 8 & 14.5 & 13.11-16. 6 & 67.7 & $44.5-87$ \\
\hline Boys \& & & & & & \\
\hline Girls & 20 & 14.0 & $10.10-16.6$ & 69.35 & $\begin{array}{ll}47 & -88\end{array}$ \\
\hline
\end{tabular}

Table 2 Hearing aids used by the children

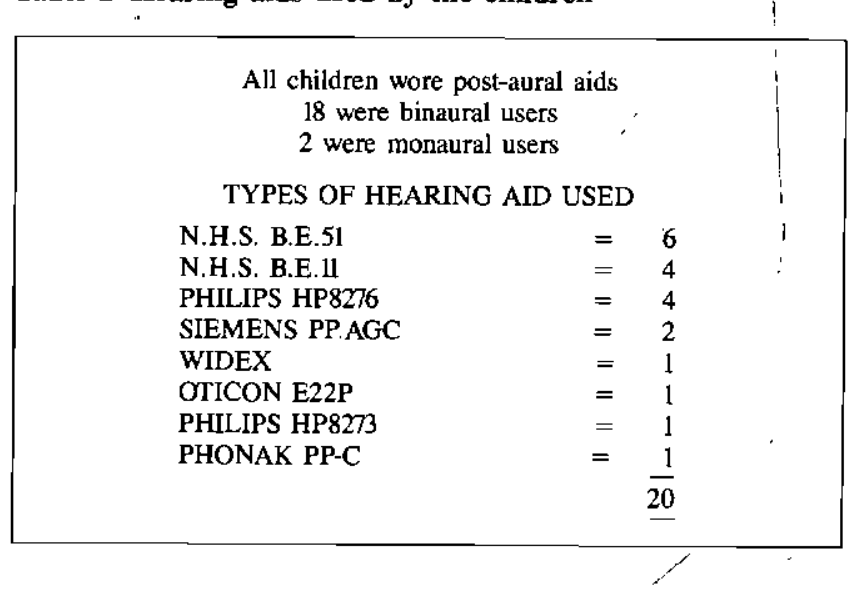

PHYSICAL ARRANGEMENT OF THE ROOM AND EQUIPMENT

The tests were carried out in an acoustically treated room measuring 18 feet by 14 feet. The floors were fully carpeted, the windows were curtained, and the walls and ceilings were covered with acoustically treated tiles. The conditions were as ideal as could be expect- 
ed. The reverberation time was within acceptable limits (approx. $0,5 \mathrm{sec}$.).

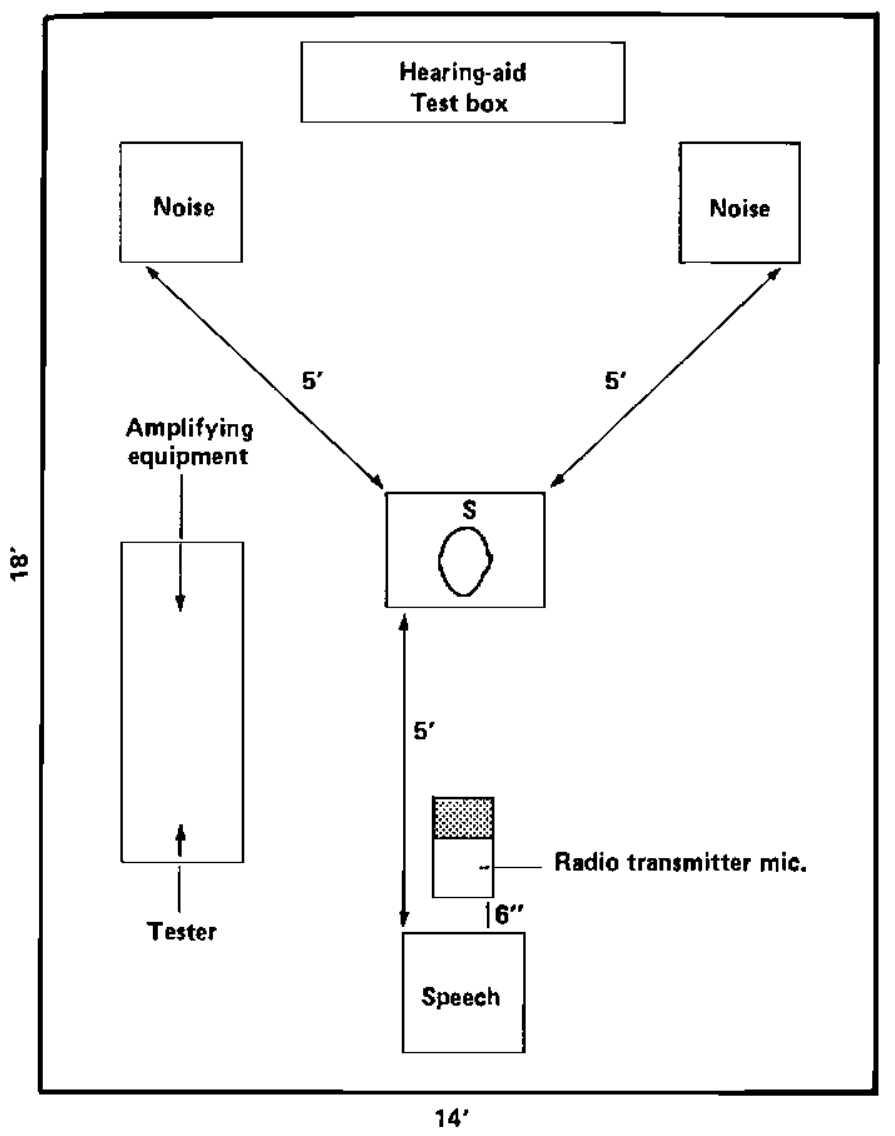

Figure 1 Physical arrangement of the free-field speech discrimination test.

Figure 1 shows the physical arrangements of the free-field speech discrimination test. The child was seated 5 feet from the speaker delivering the speech. The transmitter/microphone was supported by a chemical stand $6^{\prime \prime}$ from the speaker in order to simulate classroom/listening conditions. Two speakers delivering the wide-band noise were positioned at a $45^{\circ}$ angle to each ear of the child and placed five feet away, on a level plane with the ear.

The A.B. word lists were recorded on tape and played through a Tandberg 6000X tape recorder via a Jessops Speech Audiometer Attachment (S.A.A.) number 420 terminating in a Chartwell LS3/5A speaker. Competing noise, which was white noise shaped as cocktail party noise, was also recorded on tape and played through a Uher type 4000L tape recorder via a Jessop Speech Audiometer Attachment (SAA) number 420 terminating in two Chartwell LS3/5A speakers. Both speech audiometer attachments were calibrated at $5 \mathrm{~dB}$ intervals. The speech signal was always presented at the same intensity level of $130 \mathrm{~dB}$ (SAA) dial reading. The intensity of the competing noise (using the SAA reading) was varied accordingly to obtain signal-to-noise ratios of $+20 \mathrm{~dB},+10 \mathrm{~dB}$ and $0 \mathrm{~dB}$.

At the beginning of both the speech and the noise tapes a $1000 \mathrm{~Hz}$ pure tone was recorded for calibration purposes $(0 \mathrm{~dB} V \mathrm{VU}$ meter deflection on the SAA). The $130 \mathrm{~dB}$ dial reading for speech was equivalent to speech peaking at $70 \mathrm{dBA}$, and the $125 \mathrm{~dB}$ dial reading for noise was equivalent to $70 \mathrm{dBA}$. The measurement was carried out with a B. \& K. sound level meter Type 2203 (linear mode) at 5 feet distance from the speakers at the position where the child was seated.

\section{PROCEDURE}

\section{SPEECH DISCRIMINATION TESTING}

Each subject was tested separately using his own hearing aid on the microphone setting, using the radio neck loop with the environmental microphone, and using the radio neck loop without the environmental microphone. Subjects were tested in three signal-to-noise ratios for each mode of listening: $S / N+20 \mathrm{~dB} ; \mathrm{S} / \mathrm{N}+10 \mathrm{~dB} ; \mathrm{S} / \mathrm{N} 0 \mathrm{~dB}$.

Each subject was asked to listen carefully to speech prior to each listening condition (a few A.B. words were given) and to adjust the volume control of his hearing aid to his/her most comfortable listening level. The subject was asked to select at random a card on to which the three modes of listening, the three signal-to-noise ratios, and the word list for each listening condition were indicated in randomized order. Each child was then instructed as follows:

You are going to hear some words. You will also hear some hissing noise from the speakers behind you. Listen carefully to the words and repeat each word whatever you think you heard. Even if you hear part of a word or a word that does not make sense, or even a single sound like ' $p$ ' or ' $t$ ' please repeat it.

Children were asked to switch from using their hearing aid microphone, to using the neck loop with their hearing aids set to the telecoil position, according to the cards they selected. The environmental microphone of the radio receiver was switched on and off according to the card they had chosen.

A careful note was made of the volume setting of the hearing aids and the radio receiver as these were to be used in electroacoustic measurements after the speech discrimination test.

The responses of each child for each listening condition and at each signal-to-noise ratio were recorded on specially designed forms and later on, scored, based on the number of phonemes correctly repeated.

\section{ELECTROACOUSTIC MEASUREMENTS}

Electroacoustic measurements were carried out on the child's hearing aid using the Phonic Ear HCl000 Acoustic Test Computer.

(i) The hearing aid was tested as an ordinary aid on the microphone setting at the child's usual volume setting. The internal noise of the hearing aid in this mode was measured by pressing the TEST push button on the test box. This cuts out the signal going to the hearing aid microphone and thus a measure of the noise being generated by the hearing aid is obtained.

(ii) Measurements were then carried out with the child's hearing aid set to the telecoil position and linked to the radio receiver.

The hearing aid was coupled to the $2 \mathrm{CM}^{3}$ coupler of the test box and placed on a tailor's dummy at a position closely approximating the way the hearing aid would normally be worn by the child. The neck loop was placed around the neck of the dummy. The internal noise of the hearing aid at the telecoil setting was then measured in the manner described above. A record of all the electroacoustic measurements was made on specially designed forms and graphs were plotted.

As a final measure, the hearing aid set on the telecoil position was moved around gradually within the neckloop and observations were noted of any fluctuations in output of the aid as it was positioned in different parts, within the magnetic field created by the neck loop. After the whole sample had been tested, one third of the sample was chosen at random and re-tested on all the measures. 


\section{RESULTS}

\section{SPEECH DISCRIMINATION SCORES}

A comparison of the mean speech discrimination scores achieved with the conventional hearing aid on microphone setting and the radio neck loop at three signal-to-noise ratios is shown in Table 3. All this information is shown graphically in Fig. 2. The results were analysed using " $t$ " tests of significance to find out how the different hearing aids performed under conditions of noise.

Table 3 Comparison of mean speech discrimination scores (\% phonemes) of hearing aid microphone and radio neck loop at 3 different $S / N$ ratios. Paired $t$ test values and levels of significance are given

\begin{tabular}{|l|c|c|c|}
\hline S/N ratios & $\begin{array}{c}\text { Hearing aid } \\
\text { microphone }\end{array}$ & $\begin{array}{c}\text { Radio neck loop } \\
\text { plus Env. Mic. }\end{array}$ & $\begin{array}{c}\text { Radio neck loop } \\
\text { minus Env. Mic. }\end{array}$ \\
\hline $\mathrm{S} / \mathrm{N}+20 \mathrm{~dB}$ & $74,8 \%$ & $\begin{array}{c}72,3 \% \\
\mathrm{t}=0,62 \\
\mathrm{~N} / \mathrm{S} \text { at } 0,05 \text { or } \\
0,01 \text { level }\end{array}$ & $\begin{array}{c}66,5 \% \\
\mathrm{t}=2,08 \\
\text { significant at } \\
0,05 \text { level }\end{array}$ \\
\hline $\mathrm{S} / \mathrm{N}+10 \mathrm{~dB}$ & $57,6 \%$ & $\begin{array}{c}74,3 \% \\
\mathrm{t}=3,8 \\
\text { significant at } \\
0,05 \text { and } 0,01 \\
\text { level }\end{array}$ & $\begin{array}{c}68,1 \% \\
\mathrm{t}=2,62 \\
\text { significant at } \\
0,05 \text { and } 0,01 \\
\text { level }\end{array}$ \\
\hline $\mathrm{S} / \mathrm{N}$ OdB & $36,1 \%$ & $\begin{array}{c}63,5 \% \\
\mathrm{t}=4,85 \\
\text { signiftcant at } \\
0,05 \text { and } 0,01 \\
\text { level }\end{array}$ & $\begin{array}{c}63,5 \% \\
\mathrm{t}=4,82 \\
\text { significant at } \\
0,05 \text { and } 0,01 \\
\text { level }\end{array}$ \\
\hline
\end{tabular}

\section{$S / N+20 d B$}

The most favourable signal-to-noise ratio was $+20 \mathrm{~dB}$ when the conventional hearing aid was on its microphone setting producing a mean speech discrimination score of $74,8 \%$ and $72,3 \%$ when the radio neck loop was used with or without the environmental microphone of the radio receiver.

\section{$S / N+10 d B$}

At a signal-to-noise ratio of $+10 \mathrm{~dB}$, the performance of the hearing aid falls $17,2 \%$ while the performance of the neck loop remained much the same. At this signal-to-noise ratio there is a significant difference between the performance of the conventional hearing aid when compared to the performance of the neck loop, with and without the environmental microphone $(p>0.01)$.

\section{$S / N O d B$}

The most unfavourable signal-to-noise ratio was $0 \mathrm{~dB}$, when a marked deterioration in the performance of the conventional hearing aid on its microphone setting was noted. This represents a fall of $38,7 \%$ when considering the performance at $\mathrm{S} / \mathrm{N}+20 \mathrm{~dB}$. There is a significant difference between the performance of the conventional hearing aid and the radio neck loop ( $p>0.01$ ).

These results show that background noise affects both types of hear.ing aids but that the conventional hearing aid on its microphone setting is more adversely affected by noisy conditions. As the noise level increases the performance of the conventional hearing aid rapidly deteriorates (see Figure 2).

\section{USE OF THE ENVIRONMENTAL MICROPHONE ON RADIO RECEIVER}

Paired " $t$ " tests of significance were undertaken to find out what effect, if any, the environmental microphone had on the performance

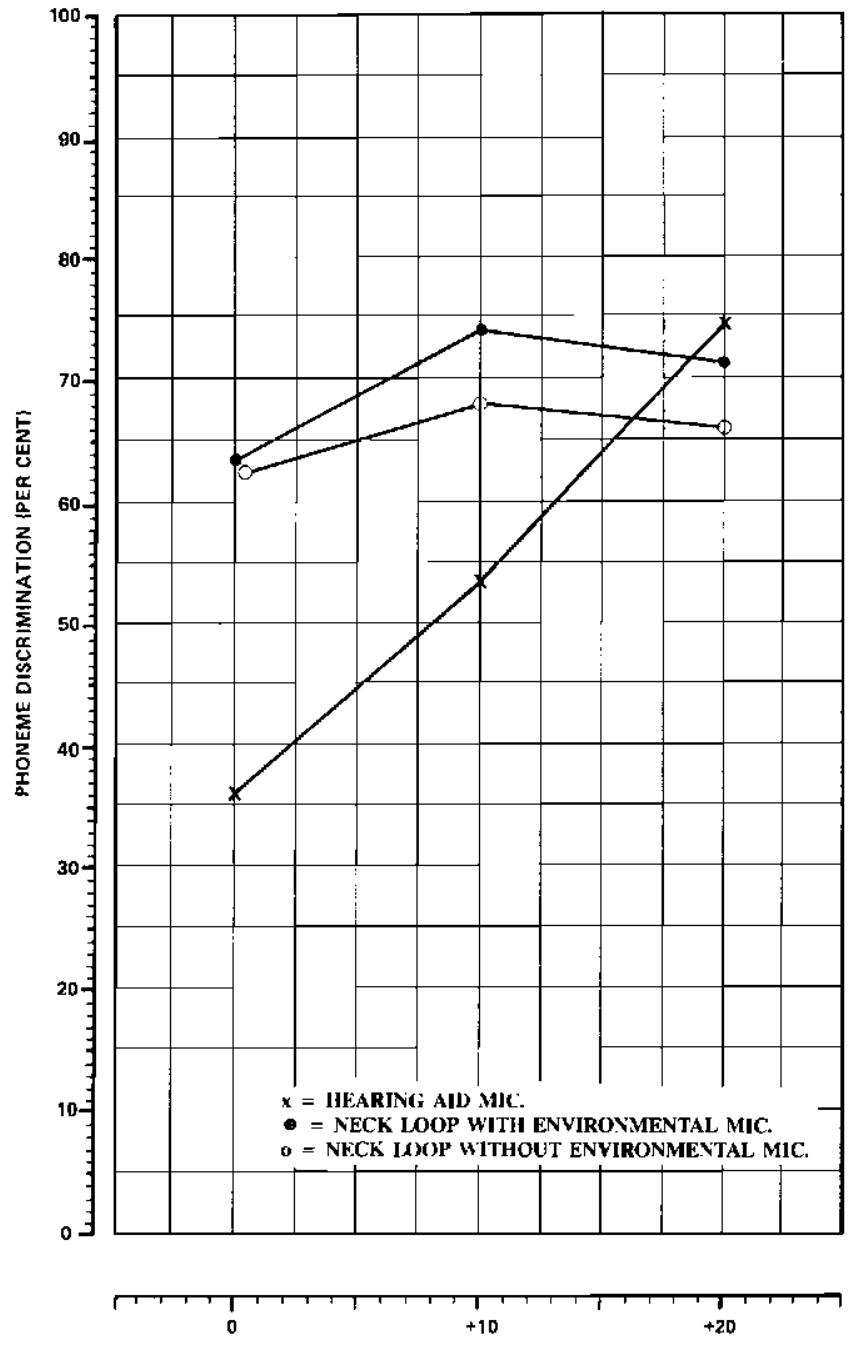

Figure 2 Mean speech discrimination scores for individual hearing aids and radio neckloop.

of the radio neck loop at the three signal-to-noise ratios used in the study. Table 4 illustrates the results and shows levels of significance.

Table 4 Comparison of mean speech discrimination scores (\% phonemes) of radio neck loop with and without use of the environmental microphone at 3 different $\mathrm{S} / \mathrm{N}$ ratios. Paired $\mathbf{t}$ test values and levels of significance are given.

\begin{tabular}{|l|c|c|}
\hline S/N ratios & $\begin{array}{c}\text { Radio neck loop } \\
\text { with } \\
\text { Env. Microphone }\end{array}$ & $\begin{array}{c}\text { Radio neck loop } \\
\text { without } \\
\text { Env. Microphone }\end{array}$ \\
\hline S/N +20dB & $72,3 \%$ & $\begin{array}{c}66,5 \% \\
=1,3 \\
\mathrm{~N} / \mathrm{S}\end{array}$ \\
\hline S/N +10dB & $74,3 \%$ & $\begin{array}{c}68,1 \% \\
=1,85 \\
\mathrm{~N} / \mathrm{S}\end{array}$ \\
& & $\begin{array}{c}63,5 \% \\
\mathrm{t}=0 \\
\mathrm{~N} / \mathrm{S}\end{array}$ \\
\hline S/N OdB & $63,5 \%$ & \\
& & \\
\hline
\end{tabular}

When the performance of the neck loop with environmental microphone was compared to its performańce without the environmental microphone at similar signal-to-noise ratios no significant differences were found. In other words, at similar signal-to-noise ratios, 
Table 5 Test-retest-reliability of speech discrimination scores mean phoneme discrimination in \%

\begin{tabular}{|c|c|c|c|c|c|c|c|c|c|c|c|c|c|c|c|}
\hline & \multicolumn{5}{|c|}{ Hearing Aid Mic. } & \multicolumn{5}{|c|}{ Radio Neckloop + Env. Mic. } & \multicolumn{5}{|c|}{ Radio Neckloop - Env. Mic. } \\
\hline & Test & S.D. & $\begin{array}{l}\text { Re- } \\
\text { test }\end{array}$ & S.D. & r & Test & S.D. & $\begin{array}{l}\text { Re- } \\
\text { test }\end{array}$ & S.D. & r & \multirow[t]{2}{*}{ Test } & \multirow[t]{2}{*}{ S.D. } & \multirow[t]{2}{*}{$\begin{array}{l}\text { Re- } \\
\text { test }\end{array}$} & \multirow[t]{2}{*}{ S.D. } & \multirow[t]{2}{*}{$r$} \\
\hline $\begin{array}{c}\text { Signal-to-noise } \\
\text { in } \mathrm{dB} . \\
+20 \mathrm{~dB}\end{array}$ & 75.5 & 14.0 & 74.9 & 11.9 & .94 & 74.9 & 15.1 & 77.1 & 13.8 & .96 & & & & & \\
\hline$+10 \mathrm{~dB}$ & 60.5 & 20.1 & 66.6 & 17.7 & .82 & 79.3 & 10.4 & 77.2 & 10.4 & .95 & 71.65 & 9.7 & 72.1 & 9.48 & .84 \\
\hline $0 \mathrm{~dB}$ & 38.85 & 26.2 & 47.15 & 20.1 & .75 & 61.5 & 16.9 & 61.0 & 16.0 & .92 & 66.1 & 21.8 & 66.5 & 15.6 & .97 \\
\hline
\end{tabular}

the use of the environmental microphone did not significantly affect discrimination for speech.

On the other hand, the use of the environmental microphone at $\mathrm{S} / \mathrm{N}$ $+20 \mathrm{~dB}$ compared to the use of the environmental microphone at $\mathrm{S} / \mathrm{N} 0 \mathrm{~dB}$ produced a significant difference at the 0.05 level of confidence. This appears to indicate that while the environmental microphone has no adverse effect on speech discrimination in reasonable levels of background noise, it should not be used in extremely noisy conditions, especially when the source of the noise is close to the environmental microphone.

\section{Test - retest reliability of speech discrimination scores}

The test retest reliability of the specch discrimination scores was ascertained by retesting a third of the sample chosen at random: The mean speech discrimination scores of the children in both the test and retest reliability sessions are shown in Table 5 . The values of the Pearson coefficient of correlation ( $r$ ) between the original and retest scores of the children are also shown. The mean scores of the children in both the test and retest sessions were very similar indicating a high degree of reliability.

\section{ELECTROACOUSTIC MEASUREMENTS}

Large differences were noted between the performance of the hearing aid on its microphone setting as compared to the performance of the hearing aid when used in the " $T$ " position, in conjunction with the neck loop. In nearly all cases the performance of the aid with the neck loop was inferior to its performance on the microphóne setting. Similar hearing aids at identical volume settings produced frequency response curves on the telecoil setting which were-sometimes vastly different.

\section{INTERNAL NOISE GENERATED BY THE HEARING AIDS}

Noise levels generated in all the hearing aids used in conjunction with the neck loop were much higher than noise levels generated in the hearing aids when used on the microphone setting. It is clear from the results that the transduction of the signal by the loop causes an increase in the internal noise that reaches the users eardrum.

Table 6 Internal noise levels (shown in $\mathrm{dB}$ ) generated in the various types of hearing aids used in the study.

\begin{tabular}{|l|c|c|c|}
\hline $\begin{array}{l}\text { Type of } \\
\text { tearing aid }\end{array}$ & $\begin{array}{c}\text { Noise } \\
\text { generated } \\
\text { on telecoil } \\
\text { setting }\end{array}$ & $\begin{array}{c}\text { Noise } \\
\text { generated } \\
\text { on mic. } \\
\text { setting }\end{array}$ & $\begin{array}{c}\text { Difference } \\
\text { in nuise } \\
\text { levels }\end{array}$ \\
\hline B.E.51 & 108 & 88 & 20 \\
B.E.11 & 88 & 68 & 20 \\
Widex AD PP & 78 & 68 & 10 \\
Otikon F22P & 98 & 78 & 20 \\
Phunak Super Front & 88 & 78 & 10 \\
Philips HP8273 & 92 & 85 & 7 \\
Siemans 24PP-AGC & 88 & 78 & 10 \\
Ptilips HP8276 & 76 & 56 & 20 \\
\hline
\end{tabular}

Table 6 shows the noise levels generated by hearing aids when used as an ordinary aid and when the aid is used with the neck loop.

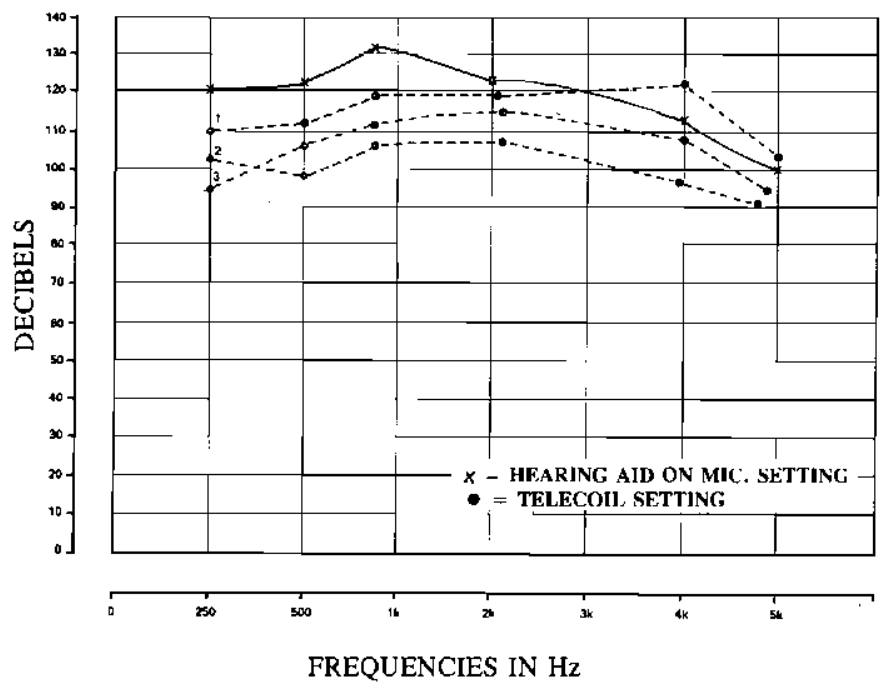

Figure 3 B.E. volume 3 rec. vol. 4.5 hearing aid set on "T" position and coupled with neckloop held at three different positions in relation to the neckloop.

THE EFFECT OF DISTANCE OF THE HEARING AID FROM THE NECK LOOP

It was found that by moving the hearing aid arbitrarily at different positions within the neck loop there was a great fluctuation in the output of the hearing aid. The effect of distance of a hearing aid from the neck loop is shown in Fig. 3 where aid B.E.11 is given as an example. Numbers 1,2 and 3 show the three different positions the hearing aid was held at in relation to the neck loop. These large differences in the output of the hearing aid could well result when children tilt their heads, or bend forwards or backwards in the course of the day. In addition, average gain will vary from child to child depending on neck lengths (Hawkins and Van Tasell 1982). Constantly fluctuating gain due to the child's head movements could be very distracting to a child and could well affect his ability to perceive speech adequately.

\section{DISCUSSION}

Most workers in the field of audiology agree that the use of speech discrimination tests both in quiet and noise is the most adequate approach to the evaluation of hearing aids. In the present study there was no statistically significant difference between conventional hearing aids normally worn by the children, and the radio neck loop at a signal-to-noise ratio $+20 \mathrm{~dB}$, that is, under good acoustic conditions. The differences only became apparent under conditions of noise.

There is no doubt that individual post-aural hearing aids, when they have been correctly prescribed, are working at maximum efficien- 
cy, and are used in good acoustic conditions have much to offer. Their most positive advantage is that they are small and hence more cosmetically acceptable. They can be worn throughout the day both in school and after school. They are more readily acceptable particularly to teenagers because they can easily be concealed.

The results of this study highlighted their excellent performance under favourable acoustic conditions. At a $\mathrm{S} / \mathrm{N}$ of $+20 \mathrm{~dB}$, their performance surpassed that of the radio neck loop, though the difference in mean discrimination scores did not approach statistical significance. However under poor acoustic conditions such as noisy classrooms and at a distance from the speaker, individual hearing aids rapidly lose their effectiveness. This study has shown that at a signal-to-noise ratio of $+10 \mathrm{~dB}$ the performance of the individual aids falls from $74,8 \%$ to $57,6 \%$ and at a signal-to-noise ratio of $0 \mathrm{~dB}$ the performance of the individual aids falls a further $21,5 \%$. Thus there is an overall deterioration of over $38 \%$ in poor acoustic conditions.

In many classroom conditions, the distance between the nearest desk and the blackboard (where the teacher would normally stand) is rarely less than six feet. At such distances a pupil using an individual hearing aid would lose much of the information which would be constantly buried in background noise. Most ordinary classrooms have high levels of background noise. This combined with distance from the teacher make individual hearing aids almost useless in such classrooms.

In recent years with accumulating evidence on the detrimental effects of noise and reverberation on speech perception, there has been widespread use of radio aids. This study confirms the need for some. type of radio system in the education of hearing impaired children. The more recent radio aids which incorporate the use of the child's individual hearing aid have become increasingly popular and at the moment seem to provide the answer to noise and reverberation problems.

An examination of the results of this study shows that the radio neck loop certainly has advantages over the individual hearing aid in conditions of noise. At a signal-to-noise ratio of $\mathrm{OdB}$ (the most unfavourable signal-to-noise ratio in this study) the performance of the individual aids falls by $38,7 \%$, while the performance of the radio neck loop falls to under $10 \%$. Furthermore the use of the environmental microphone does not adversely affect speech discrimination scores at any of the signal-to-noise ratios in this investigation. This is an important consideration as it is vital for children to be able to heār their own voices and environmental sounds.

It is important to bear in mind that the scores achieved with the use of the neck loop in this study relate to a group of children who normally make extensive use of the inductance loop at school and have been doing so for several years now. The children use the telecoil facility of their hearing aids to watch television. They use it in the hall and chapel almost daily and most of the classrooms are looped. These children then, have extensive experience of perceiving speech through the telecoil facility of their hearing aids. Young, inexperienced hearing aid users who have not been exposed to similar experience of using the telecoil facility of their hearing aids might "not be in a similar position and may suffer a loss in speech discrimination resulting from the changes in the frequency response of the hearing aid which take place.

Secondly, during the test situation, children sat upright with the neck loop carefully positioned around their necks and there was little likelihood of fluctuation in the strength of the speech signal. This is not the case in the day-to-day use of the radio neck loop in a classroom where children are moving around and moving their heads from side to side. The teacher cannot assume that the child using the radio neck loop is receiving the same signal as when the individual hearing aid is worn in the microphone mode. All the hearing aids used in the study showed that when the hearing aid was used in conjunction with the neck loop, there was a change in the frequency response of the hearing aid. In most cases the greatest change occurred in the lower region of the frequency range. This would therefore have serious limitations for profoundly hearing impaired children who depend almost entirely on lower frequencies for their information.

The study also showed that the location of the hearing aid in relation to the neck loop is a critical variable and a matter of great concern to users of the neck loop. The great fluctuation in the output of the hearing aid as it is moved around within the neck loop can cause the child to lose audibility of the signal as he moves his head about. Older children who are experienced hearing aid users, and those who have less severe hearing impairments, may be sensitive to this and make the necessary adjustments. Young, inexperienced hearing aid users are less discriminating in their use of hearing aids and will suffer a loss in perception of the speech signal.

The general implication resulting from this study is that more attention should be given to the performance characteristics of hearing aids used in conjunction with the radio neckloop. Not only do different hearing aids show different sensitivity for loop induction, but when hearing aids are chosen for their performance on the microphone setting, these advantages are lost when the hearing aid is coupled to the radio neck loop and has to be used on the telecoil setting of the aid. In view of the number of limitations that the radio neck loop has, it should not be the radio system of choice when considering the provision of radio systems for children.

What is required is a system that offers all the advantages of reducing noise and reverberation and yet preserves the frequency response of the hearing aid that has been prescribed for the child. The performance of a radio microphone hearing aid system should be equivalent on both audio and radio channels. This means that a child does not suffer from the change that takes place in the frequency response of the aid when it is switched from the microphone to the telecoil setting. Direct audio-input seems to be the answer to this problem. In the study by Hawkins and Van Tasell (1982) it was shown that hearing aids showed a remarkable similarity in frequency response when used with the direct audio input facility, in contrast to the variable and often unpredictable, microphone-telecoil differences.

There is a wide range of hearing aids on the market today and there is more flexibility in the way they can be adjusted to cater for a variety of different hearing losses. Individual aids can therefore be chosen and set as far as possible to cater for the special needs of each child's hearing loss. As hearing aids are prescribed largely on the basis of their microphone performance it would make sense to preserve this frequency response while at the same time offering the child the benefits of reduced noise and reverberation that audio input would provide. In addition, the direct audio input system is not susceptible to the effects of distance and hearing aid orientation that has been noticed with the aid coupled to the radio neck loop. Thus a child whose hearing aid was specifically prescribed because of the low frequency emphasis which it afforded him would not be at a disadvantage in this respect when the aid was uséd in conjunction with the audio input facility.

\section{ACKNOWLEDGEMENTS}

The author wishes to express his thanks to: the children at Ovingdean Hall School in Brighton where much of this study was under- 
taken; Dr Michael Nolan of the Department of Audiology, Manchester University for his advice and assistance with this study; and Mr R. Bennett, County Hall, Beverley for his assistance with the illustrations.

\section{REFERENCES}

Barr Hamilton, R.M.A. A Theoretical Approach to the Loop Induction System. Brit. J. Audio., 12, 135-139, 1978.

Bates, A. and Holsgrove, G. The Phonic Ear. Teacher of the Deaf, (3), 5, 154-170, 1979.

Borrild, K. The Induction Loop and its Possibilities. In G. Liden (Ed.) Geriatric Audiology, Almquist and Wiksell, Stockholm, 1968.

Finitzo-Hieber, T., and Tillman, T.W. Room Acoustics Effect on Monosyllabic Word Discrimination Ability for Normal and Hearing Impaired Children. J. Speech Hear. Res. , 21, 440-458, 1978.

Gengel, R.W. Acceptable Speech-to-Noise Ratios for Aided Speech Discrimination by the Hearing Impaired. J. Audio. Res., Il, 219-222, 1971.

Hawkins, D.B., and Van Tasell, D.J. Electroacoustic Characteristics of Personal F.M. Systems. J. Speech Hear Disord., 47, 355-362, 1982.

Hodgson, W.R., and Sung, R.J. Performance of Individual Hearing Aids Utilizing Microphone and Induction Coil Input. $J$. Speech Hear. Res., 14, 365-371, 1971.

Huntingdon, A. Tests on Induction Loops in Current Use in Schools for the Deaf. Teacher of the Deaf, 74, 7-18, 1976.

John, J.E.J. Acoustics in the Use of Hearing Aids: Educational Guidance and the Deaf Child. Manchester University press, 1957.
Markides A. Huntingdon, A., and Kettlety, A. Comparison of Speech Discrimination Abilities through Infra Red Radio and Conventional Hearing Aids. Teacher of the Deaf, (4), 5-14, 1980.

Matkin, N. and Oslen, W. Response of Hearing Aids with Induction Loop Amplification systems, Amer. Annals Deaf, 115, 73-78, 1970.

Nabelek, A.K., and Pickett, J.M. Monaural and Binaural Speech Perception through Hearing Aids under Noise and Reverberation with Normal and Hearing Impaired Listeners. J. Speech Hear. Res., 17, 724-739, 1974.

National Council for Teachers of the Deaf. The Phonic Ear HC42I FM Stereo Hearing Aid. Northern Branch Hearing Aid SubCommittee Report. National Council for Teachers of the Deaf. U.K., 1976.

Nolan, M. Hearing Aids for Children. Teacher of the Deaf, (6) 5, 122, 1982.

Ross, M., and Giolas, T.G. Audiology Management of Hearing $1 m$ paird Children: Principles and Prerequisites for Intervention, University Park Press, Baltimore, 1980.

Sanders, D. Noise Conditions in Normal School Classrooms - Excep. Children, 31, 344-551, 1965.

Sung, R.J. Sung, G.S., and Hodgson, W.R. Telecoil Versus Microphone Performance in Hearing Aids. Volta Review, 19, 15, 417-424, 1973.

Vargo, S.W., Taylor G., and Tannahill, J.C. The Intelligibility of Speech by Hearing Aids on Induction Loop and Microphone Modes of Signal Reception. J. Speech Hear. Res., 13, 87-91, 1970.

Address for reprints: T.A. Moodley, Hearing Impaired Service, Lowfield Lane, Melton, N. Ferriby, N. Humberside, HU14 3HT, England. 


\section{Aids for}

- the development of perception

- the acquisition of speech and language skills

- the improvement of motor co-ordination

\section{Plus}

- helpful texts for therapists

- educational toys, books and equipment

- records for auditory training

- catalogues on request

- large variety of tests available

\section{Stockists of}

- Learning to Listen

- Two sound lottos

- Full LDA range

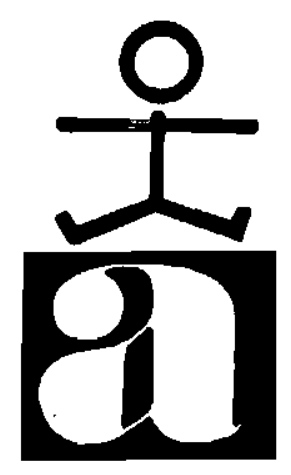

PLAY AND SCHOOLROOM

44 President Place,

148 Jan Smuts Ave., Rosebank.

Telephone 788-1304

P.O. Box 47288, Parklands 2121. 


\section{INFORMATION FOR CONTRIBUTORS}

The South African Journal of Communication Disorders publishes reports and papers concerned with research, or critically evaluative theoretical, or therapeutic issues dealing with disorders of speech, voice, hearing or language, or on aspects of the processes underlying these.

The South African Journal of Communication Disorders will not accept material which has been published elsewhere or that is currently under review by other publications.

All contributions are reviewed by at least two consultants who are not provided with author identification.

Form of Manuscript. Authors should submit four neatly typewritten manuscripts in triple spacing with wide margins which should not exceed much more than 25 pages. Each page should be numbered. The first page of two copies should contain the title of the article, name of author/s, highest degree and address or institutional affiliation. The first page of the remaining two copies should contain only the title of the article. The second page of all copies should contain only an abstract (100 words) which should be provided in both English and Afrikaans. Afrikaans abstracts will be provided for overseas contributors. All paragraphs should start at the left margin and not be indented.

Major headings, where applicable, should be in the order of METHOD, RESULTS, DISCUSSION, CONCLUSION, ACKNOWLEDGEMENTS and REFERENCES.

Tables and Figures should be prepared on separate sheets (one per table/figure). Figures, graphs and line drawings must be originals, in black ink on good quality white paper. Lettering appearing on these should be uniform and professionally done, bearing in mind that such lettering should be legible after a $50 \%$ reduction in printing. On no account should lettering be typewritten on the illustration. Any explanation or legend should not be included in the illustration but should appear below it. The titles of tables and figures should be concise but explanatory. The title of tables appears above, and of figures below. Tables and figures should be numbered in order of appearance (with Arabic numerals). The amount of tabular and illustrative material allowed will be at the discretion of the Editor (usually not more than 6). References. References should be cited in the text by sumame of the author and date, e.g. Van Riper (1971). Where there are more than two authors, et al. after the first author will suffice. The names of all authors should appear in the Reference List. References should be listed alphabetically in triple-spacing at the end of the article. For acceptable abbreviations of names of journals, consult the fourth issue (October) of DSH ABSTRACTS or The World List of Scientific Periodicals. The number of references used should not exceed much more than 20.

Note the following examples:

Locke, J.L. Clinical Phonology: The Explanation and Treatment of Speech Sound Disorders. J. Speech Hear. Disord. , 48, 339-341, 1983. Penrod, J.P. Speech Discrimination Testing. In J. Katz (Ed.) Handbook of Clinical Audiology, 3rd ed., Baltimore: Williams \& Wilkins, 1985.

Van Riper, C. The Nature of Stuttering. Englewood Cliffs, New Jersey: Prentice-Hall, 1971.

Proofs. Galley proofs will be sent to the author wherever possible. Corrections other than typographical errors will be charged to the author.

Reprints. 10 reprints without covers will be provided free of charge. All manuscripts and correspondence should be addressed to:

The Editor,

South African Journal of Communication Disorders,

South African Speech and Hearing Association,

P.O. Box 31782, Braamfontein 2017, South Africa.

\section{INLIGTING VIR BYDRAERS}

Die Suid-Afrikacanse Tydskrif vir Kommunikasieafwykings publiseer verslae en artikels oor navorsing, of krities evaluerende artikels oor die teoretiese of terapeutiese aspekte van spraak-, stem-, gehoor- of taalafwykings, of oor aspekte van die prosesse onderliggend aan hierdie afwykings.

Die Suid-Afrikaanse Tydskrif vir. Kommunikasieafwykings sal nie materiaal aanvaar wat reeds elders gepubliseer is, of wat tans deur ander publikasies oorweeg word nie.

Alle bydraes word deur minstens twee konsultante nagegaan wat nie ingelig is oor die identiteit van die skrywer nie.

Formaat van die Manuskrip. Skrywers moet vier netjies getikte manuskripte in 3-spasiëring en met breë kantlyn indien, en dit moet nie veel langer as 25 bladsye wees nie. Elke bladsy moet genommer wees.

Op die eerste bladsy van 2 afskrifte moet die titel van die artikel, die naam van die skrywer/s, die hoogste graad behaal en die adres of naam van hulle betrokke instansie verskyn. Op die eerste bladsy van die oorblywende twee afskrifte moet slegs die titel van die artikel verskyn. Die tweede bladsy van alle afskrifte moet slegs 'n opsomming (100 woorde) in beide Engels en Afrikaans bevat. Afrikaanse opsommings sal vir buitelandse bydraers voorsien word. Alle paragrawe moet teenaan die linkerkantlyn begin word en moet nie ingekeep word nie.

Hoofopskrifte moet, waar dit van toepassing is, in die volgende volgorde wees: METODE, RESULTATE, BESPREKING, GEVOLGTREKKING, ERKENNINGS en VERWYSINGS.

Tabelle en Figure moet op afsonderlike bladsye verskyn (een bladsy per tabel/illustrasie). Figure, grafieke en lyntekeninge moet oorspronklike weergawes wees en moet in swart ink op wit papier van 'n hoë gehalte gedoen word.

Letterwerk wat hierop verskyn moet eenvormig wees, professioneel gedoen word en daar moet in gedagte gehou word dat dit leesbaar moet wees na 'n $\mathbf{5 0 \%}$-verkleining in drukwerk. Letterwerk by die illustrasie moet onder geen omstandighede getik word nie.
Verklarings of omskrywings moet nie ín die illustrasie nie, maar daaronder verskyn. Die byskrifte van tabelle moet bo-aan verskyn en dié van figure onderaan. Tabelle en figure moet in die volgorde waarin hulle verskyn genommer word (met Arabiese syfers). Die hoeveelheid materiaal in die vorm van tabelle en illustrasies wat toegelaat word, word deur die redakteur bepaal (gewoonlik nie meer as 6 nie). Verwysings. Verwysings in die teks moet voorsien word van die skrywer se van en die datum bv. Van Riper (1979). Waar daar meer as twee skrywers is, sal $e t$ al. na die eerste skrywer voldoende wees. Die name van alle skrywers moet in die Verwysingslys verskyn. Verwysings moet alfabeties in 3-spasiëring aan die einde van die artikel gerangskik word. Vir die aanvaarde afkortings van tydskrifte se titels, raadpleeg die vierde uitgawe (Oktober) van DSH ABSTRACTS of The World List of Scientific Periodicals. Die getal verwysings wat gebruik is, moet nie veel meer as 20 wees nie.

Let op die volgende voorbeelde:

Locke, J.L. Clinical Phonology: The Explanation and Treatment of Speech Sound Disorders. J. Speech Hear. Disord., 48, 339-341, 1983. Penrod, J.P. Speech Discrimination Testing. In J. Katz (Ed.) Handbook of Clinical Audiology, 3de ed., Baltimore: Williams \& Wilkins, 1985.

Van Riper, C. The Nature of Stuttering. Englewood Cliffs, New Jersey: Prentice-Hall, 1971.

Proewe. Galeiproewe sal waar moontlik aan die skrywer gestuur word. Die onkoste van veranderinge, behalwe tipografiese foute, sal deur die skrywer self gedra moet word.

Herdrukke. 10 herdrukke sonder omslae sal gratis verskaf word. Alle manuskripte en korrespondensie moet gerig word aan:

Die Redakteur,

Die Suid-Afrikaanse Tydskrif vir Kommunikasieafwykings.

Die Suid-Afrikaanse Vereniging vir Spraak- en Gehoorheelkunde, Posbus 31782,

BRAAMFONTEIN 2017, SUID-AFRIKA. 